\section{MERS-CoV in Camels but Not Camel Handlers, Sudan, 2015 and 2017}

\author{
Elmoubasher Farag, ${ }^{1}$ Reina S. Sikkema, ${ }^{1}$ \\ Ahmed A. Mohamedani, Erwin de Bruin, \\ Bas B. Oude Munnink, Felicity Chandler, \\ Robert Kohl, Anne van der Linden, \\ Nisreen M.A. Okba, Bart L. Haagmans, \\ Judith M.A. van den Brand, Asia Mohamed Elhaj, \\ Adam D. Abakar, Bakri Y.M. Nour, \\ Ahmed M. Mohamed, Bader Eldeen Alwaseela, \\ Husna Ahmed, Mohd Mohd Alhajri, \\ Marion Koopmans, Chantal Reusken, ${ }^{2}$ \\ Samira Hamid Abd Elrahman²
}

Author affiliations: Ministry of Public Health, Doha, Qatar (E. Farag, M.M. Alhajri); Erasmus Medical Centre, Rotterdam, the Netherlands (R.S. Sikkema, E. de Bruin, B.B.O. Munnink, F. Chandler, R. Kohl, A. van der Linden, N.M.A. Okba,

B.L. Haagmans, M. Koopmans, C. Reusken); University of Gezira, Wad Medani, Sudan (A.A. Mohamedani,

S.H. Abd Elrahman); Utrecht University, Utrecht, the Netherlands (J.M.A. van den Brand); Blue Nile National Institute for Communicable Diseases, Wad Medani (A.M. Elhaj, A.D. Abakar, B.Y.M. Nour, A.M. Mohamed, S.H. Abd Elrahman); Tamboul Camel Research Centre, Tamboul, Sudan (B.E. Alwaseela, H. Ahmed); National Institute |for Public Health and the Environment, Bilthoven, the Netherlands (C. Reusken)

DOI: https://doi.org/10.3201/eid2512.190882

We tested samples collected from camels, camel workers, and other animals in Sudan and Qatar in 2015 and 2017 for evidence of Middle East respiratory syndrome coronavirus (MERS-CoV) infection. MERS-CoV antibodies were abundant in Sudan camels, but we found no evidence of MERSCoV infection in camel workers, other livestock, or bats.

$\mathrm{M}$ iddle East respiratory syndrome coronavirus (MERS$\mathrm{CoV}$ ) is a zoonotic virus from camels that can cause serious respiratory disease and death in humans (1). Camel populations across the Middle East and Africa are highly seropositive. However, the only known human cases of clinical MERS-CoV infection in Africa were related to travel from Qatar and Saudi Arabia (https://ecdc.europa.eu/ sites/portal/files/media/en/publications/Publications/RRA MERS-CoV_7th_update.pdf), and serologic evidence for infections in humans resulting from camel exposure in Africa is limited (2).

${ }^{1}$ These first authors contributed equally to this article.

${ }^{2}$ These authors were co-principal investigators.
The only published report of MERS-CoV circulation in camels in Sudan involved the testing of camel samples from 1983; that study found a seroprevalence of $82 \%$ (49/60) (3). Two publications from Egypt describe evidence of possible MERS-CoV circulation in Sudan, reporting a seroprevalence of $91 \%(543 / 594)$ in camels originating from Sudan and a seroprevalence of $92 \%$ (48/52), combined with a reverse transcription PCR positivity rate of $5.6 \%$, in camels originating from Ethiopia and Sudan (3). Neither study presented conclusive evidence for MERS$\mathrm{CoV}$ circulation in Sudan. Here, we provide the results of a study conducted in the Butana region of Al Gezira, Sudan, to investigate the local point prevalence of MERS-CoV and MERS-CoV antibodies among camel handlers, camels, and other animals in 2015 and 2017. We also report the results of a MERS-CoV screening in camels from Sudan sampled in Qatar directly upon importation.

We collected samples from humans and animals at a live animal market, an outdoor slaughter area adjacent to that market, and the Tamboul Camel Research Centre (TCRC), all located in Tamboul, Sudan. Overall, $\approx 1,660$ camels and additional other livestock are usually present at the animal market; these camels come from individual small farms, where they are largely kept under free-roaming conditions. At the TCRC, $\approx 100$ camels are generally present and kept out of contact with other camels. Before their arrival at the TCRC, they were herded on the Butana Plain. We also collected samples from 90 Sudan camels that were imported into Qatar in 2015. After arriving at the Hamad International Airport in Doha, Qatar, these camels were directly transported to the Al Shahaniya animal market in Doha. We sampled them immediately after their arrival. We stored all samples locally (1-1.5 years in Sudan, 1 month in Qatar) and tested them after shipment to the Netherlands.

We tested 56 human, 190 camel, 3 bat, 14 donkey, 15 cow, 15 sheep, and 15 goat serum samples for antibodies against MERS-CoV spike S1 using the protein microarray technique (4). We performed a virus neutralization test and a spike S1 protein-based ELISA (human serum samples only) to confirm the detection of MERS-CoV antibodies by protein microarray (5). In confirmatory tests, we included equal numbers of negative serum samples of the same species, when available. We considered samples positive if results of all tests were positive (protein microarray cutoff $1: 20,50 \%$ plaque-reduction neutralization titer cutoff 1:20, ELISA cutoff optical density 0.5 ). To resolve problems with possible mislabeling, we tested all animal serum samples collected in 2017 with a cytochrome B gene PCR to confirm species origins (6). We tested camel nasal $(\mathrm{n}=168)$, nasopharyngeal $(\mathrm{n}=24)$, and rectal $(\mathrm{n}=61)$ swab specimens and milk $(\mathrm{n}=33)$, urine $(\mathrm{n}=30)$, and fecal $(n=42)$ samples for MERS-CoV RNA using a reverse 
Table. MERS-CoV RNA and antibody positivity among humans, bats, camels, and other livestock, Sudan, 2015 and $2017^{\star}$

\begin{tabular}{|c|c|c|c|c|c|c|c|}
\hline \multirow[b]{2}{*}{ Sample type } & \multirow[b]{2}{*}{$\begin{array}{c}\text { Location of sample } \\
\text { collection }\end{array}$} & \multicolumn{3}{|c|}{2015} & \multicolumn{3}{|c|}{2017} \\
\hline & & $\begin{array}{c}\text { No. } \\
\text { samples }\end{array}$ & $\begin{array}{l}\text { MERS-CoV } \\
\text { RNA, no. } \\
\text { positive/total } \\
\text { no. }(\%)\end{array}$ & $\begin{array}{l}\text { MERS-CoV } \\
\text { antibody, no. } \\
\text { positive/total } \\
\text { no. }(\%)\end{array}$ & $\begin{array}{c}\text { No. } \\
\text { samples }\end{array}$ & $\begin{array}{l}\text { MERS-CoV } \\
\text { RNA, no. } \\
\text { positive/total } \\
\text { no. }(\%)\end{array}$ & $\begin{array}{l}\text { MERS-CoV } \\
\text { antibody, no. } \\
\text { positive/total } \\
\text { no. }(\%)\end{array}$ \\
\hline \multirow[t]{3}{*}{ Camel worker serum } & Tamboul slaughter area & 3 & NT & ND & 35 & NT & ND \\
\hline & Tamboul market & 8 & NT & ND & NA & & \\
\hline & TCRC & 7 & NT & ND & 3 & NT & ND \\
\hline \multirow[t]{4}{*}{ Camel serum $\dagger$} & Tamboul slaughter area $\S$ & 4 & ND & $4 / 4(100)$ & 13 & ND & $13 / 13(100)$ \\
\hline & Tamboul marketł§I & 27 & ND & $26 / 27(96)$ & NA & & \\
\hline & TCRCף & 31 & ND & $27 / 31(87)$ & 25 & ND & $25 / 25(100)$ \\
\hline & Qatar§币\# & 90 & ND & $89 / 90(99)$ & NA & & \\
\hline $\begin{array}{l}\text { Camel nasopharyngeal } \\
\text { swabs } \dagger\end{array}$ & TCRCI & NA & & & 24 & ND & NT \\
\hline \multirow[t]{4}{*}{ Camel nasal swabs $†$} & Tamboul slaughter areał§ & 11 & ND & NT & NA & & \\
\hline & Tamboul marketł§I & 11 & ND & NT & NA & & \\
\hline & TCRCT & 31 & ND & NT & 25 & ND & NT \\
\hline & Qatar§币\#** & 90 & $3 / 90(3)$ & NT & NA & & \\
\hline $\begin{array}{l}\text { Camel ticks (Hyalomma } \\
\text { dromedarii) from } 25 \\
\text { camels }\end{array}$ & TCRC & 155 & ND & NT & NA & & \\
\hline \multicolumn{8}{|l|}{ Other animal serum } \\
\hline Cattle & Tamboul slaughter area & 6 & ND & ND & 9 & NT & ND \\
\hline Goat & Tamboul slaughter area & 5 & ND & ND & 10 & NT & ND \\
\hline Sheep & Tamboul slaughter area & 5 & ND & ND & 10 & NT & ND \\
\hline Donkey & Tamboul slaughter area & 5 & ND & ND & 9 & NT & ND \\
\hline Bat†† & TCRC & 3 & ND & NT & NA & & \\
\hline Bat tissue $\ddagger \ddagger$ & TCRC & 13 & ND & NT & NA & & \\
\hline \multicolumn{8}{|l|}{$\begin{array}{l}\text { *MERS-CoV, Middle East } \\
\text { Centre. } \\
\text { †From camels >2 years o } \\
\text { †Serum and swab sample } \\
\text { §Sample set included me } \\
\text { ๆSample set included milk } \\
\text { \#Sample set included rac } \\
\text { \#*Just imported into Qatar }\end{array}$} \\
\hline
\end{tabular}

transcription PCR targeting the upstream of envelope and nucleocapsid genes, as described previously $(7,8)$. In addition, we tested legs of camel ticks (Hyalomma dromedarii) and bat (Tadarida spp.) tissues collected at the TCRC in 2015 for MERS-CoV RNA.

In 2015 , a total of $92 \%$ of camels in Sudan and $99 \%$ of camels exported to Qatar from Sudan were MERS-CoV seropositive (Table). In 2017, all camels tested in Sudan were seropositive. No MERS-CoV antibodies were found in human or bat serum samples or serum samples from livestock other than camels. MERS-CoV RNA was detected in the nasal swabs from 3 camels imported into Qatar in 2015 but in no other samples.

The results of this study are in agreement with other seroepidemiologic studies performed in Africa. The camel population was highly seropositive for MERS-CoV, and none or a low percentage of nasal or nasopharyngeal swabs from camels were positive for MERS-CoV RNA. As shown before in other countries in Africa, human serum samples did not show neutralizing activity against MERS-CoV (2). In 1 study in Kenya, 2 of 1,122 livestock handlers were found positive for MERS-CoV neutralizing antibodies (9).
Other livestock were also seronegative for MERS-CoV in our study, a finding in agreement with most serosurveys, although some sheep, goats, and donkeys and 1 cow have been reported to have MERS-CoV antibodies $(3,10)$.

The number of human and livestock samples tested was low in this investigation. Therefore, the results of this study are not conclusive. However, this study provides preliminary insight into MERS-CoV circulation in Sudan, the country with the third largest dromedary camel population in the world (http://www.fao.org/faostat/en/\#data/QA). We show evidence of extensive MERS-CoV circulation in camels but no evidence of circulation in other livestock, bats, and humans.

This work was supported by grants from the European Commission's H2020 program under contract number 643476 (http://www.compare-europe.eu) and CRDF Global (project no. 61211/61210).

\section{About the Author}

Mr. Farag is acting head of the Communicable Diseases Control Programs, Ministry of Public Health, Doha, Qatar, and a doctoral 
candidate at the Erasmus Medical Centre. His research interests are mainly the epidemiology of MERS-CoV and spread of MERS-CoV at the human-animal interface. Ms. Sikkema is a doctoral candidate at the Erasmus Medical Centre, Rotterdam, the Netherlands. Her research interests are mainly focused on the risk-based surveillance of MERS-CoVs in animals and humans.

\section{References}

1. Reusken CB, Raj VS, Koopmans MP, Haagmans BL. Cross host transmission in the emergence of MERS coronavirus. Curr Opin Virol. 2016;16:55-62. https://doi.org/10.1016/ j.coviro.2016.01.004

2. So RT, Perera RA, Oladipo JO, Chu DK, Kuranga SA, Chan KH, et al. Lack of serological evidence of Middle East respiratory syndrome coronavirus infection in virus exposed camel abattoir workers in Nigeria, 2016. Euro Surveill. 2018;23. https://doi.org/10.2807/1560-7917.ES.2018.23.32.1800175

3. Sikkema RS, Farag EABA, Islam M, Atta M, Reusken CBEM, Al-Hajri MM, et al. Global status of Middle East respiratory syndrome coronavirus in dromedary camels: a systematic review. Epidemiol Infect. 2019;147:e84. http://dx.doi.org/10.1017/ S095026881800345X

4. Reusken CBEM, Haagmans BL, Müller MA, Gutierrez C, Godeke G-J, Meyer B, et al. Middle East respiratory syndrome coronavirus neutralising serum antibodies in dromedary camels: a comparative serological study. Lancet Infect Dis. 2013;13:859-66. https://doi.org/10.1016/ S1473-3099(13)70164-6

5. Okba NMA, Raj VS, Widjaja I, Geurts van Kessel CH, de Bruin E, Chandler FD, et al. Sensitive and specific detection of low-level antibody responses in mild Middle East respiratory. Emerg Infect Dis. 2019;25:1868-77. http://dx.doi.org/10.3201/ eid2510.190051

6. Kocher TD, Thomas WK, Meyer A, Edwards SV, Pääbo S, Villablanca FX, et al. Dynamics of mitochondrial DNA evolution in animals: amplification and sequencing with conserved primers. Proc Natl Acad Sci U S A. 1989;86:6196-200. https://doi.org/10.1073/pnas.86.16.6196

7. Corman VM, Eckerle I, Bleicker T, Zaki A, Landt O, Eschbach-Bludau M, et al. Detection of a novel human coronavirus by real-time reverse-transcription polymerase chain reaction. Euro Surveill. 2012;17:20285. https://doi.org/10.2807/ ese.17.39.20285-en

8. Corman VM, Müller MA, Costabel U, Timm J, Binger T, Meyer B, et al. Assays for laboratory confirmation of novel human coronavirus (hCoV-EMC) infections. Euro Surveill. 2012;17:20334. https://doi.org/10.2807/ese.17.49.20334-en

9. Liljander A, Meyer B, Jores J, Müller MA, Lattwein E, Njeru I, et al. MERS-CoV antibodies in humans, Africa, 2013-2014. Emerg Infect Dis. 2016;22:1086-9. https://doi.org/10.3201/ eid2206.160064

10. Kandeil A, Gomaa M, Shehata M, El-Taweel A, Kayed AE, Abiadh A, et al. Middle East respiratory syndrome coronavirus infection in non-camelid domestic mammals. Emerg Microbes Infect. 2019;8:103-8. https://doi.org/10.1080/22221751.2018. 1560235

Address for correspondence: Samira Hamid Abd Elrahman, University of Gezira, Blue Nile National Institute for Communicable Diseases, PO Box 101, Wad Medani, Gezira, Sudan; email: samhamid2002@yahoo.co.uk

\section{Recombination between Vaccine and Field Strains of Porcine Reproductive and Respiratory Syndrome Virus}

\author{
Anping Wang, Qi Chen, Leyi Wang, \\ Darin Madson, Karen Harmon, Phillip Gauger, \\ Jianqiang Zhang, Ganwu Li
}

Author affiliations: Jiangsu Agri-animal Husbandry Vocational College, Taizhou, China (A. Wang); lowa State University, Ames, lowa, USA (A. Wang, Q. Chen, D. Madson, K. Harmon, P. Gauger, J. Zhang, G. Li); University of Illinois, Urbana, Illinois, USA

(L. Wang); Chinese Academy of Agricultural Sciences, Harbin, China (G. Li)

DOI: https://doi.org/10.3201/eid2512.191111

We isolated and plaque-purified IA76950-WT and IA70388$\mathrm{R}, 2$ porcine reproductive and respiratory syndrome viruses from pigs in the same herd in lowa, USA, that exhibited coughing and had interstitial pneumonia. Phylogenetic and molecular evolutionary analysis indicated that IA70388-R is a natural recombinant from Fostera PRRSV vaccine and field strain IA76950-WT.

P orcine reproductive and respiratory syndrome (PRRS), characterized by reproductive failure in sows and respiratory distress in pigs of all ages, causes substantial economic loss to the worldwide swine industry. PRRS virus (PRRSV) is an enveloped, single-stranded, and positive-sense RNA virus belonging to the family Arteriviridae (1). Historically, PRRSV comprises type 1 (PRRSV-1) and type 2 (PRRSV-2); recently, PRRSV-1 was taxonomically classified into the species Betaarterivirus suid 1 and PRRSV-2 into the species Betaarterivirus suid 2. PRRS has remained the most important disease of swine throughout the world, and live attenuated vaccines are used to reduce the clinical impact of PRRSV infection. Several studies have reported that recombinant PRRSV strains emerged in China, Korea, and France because of recombination between wild-type and vaccine strains (2-6). Nevertheless, recombination between a live attenuated vaccine strain and a circulating strain has not been reported in the United States.

In October 2018, a farm with a history of using Fostera PRRSV vaccine had been experiencing an ongoing problem with porcine respiratory disease. Histopathologic examination of 2 samples (lungs A and B) revealed the lungs of both pigs demonstrated significant interstitial pneumonia. Open reading frame (ORF) 5 Sanger sequencing identified a wild-type PRRSV from sample A 